\title{
China's Military and the Belt and Road Initiative: a View from the Outside
}

\author{
Joshua Andresen \\ University of Surrey, UK \\ j.andresen@surrey.ac.uk
}

\begin{abstract}
China's Belt and Road Initiative (BRI) is the largest investment in global infrastructure of all time, easily outpacing the United States' Marshall Plan following World War II. Despite the BRI's aspirations, it has been called into question from an increasing range of perspectives. This article focuses on security questions raised from the American perspective. By placing the BRI in historical and global perspective, I will critically evaluate the questions raised by American observers in order to separate the concerns we should take seriously from those that are overblown. The Belt and Road initiative and accompanying military buildup have been heralded as a fundamental change in the global order. Whether that is the case, of course, remains to be seen. What is certain, however, is that the balance of regional economic and military power is undergoing a dramatic change.
\end{abstract}

\section{Keywords}

international law - Belt and Road Initiative - foreign relations - armed conflict

China's Belt and Road Initiative (BRI) is the largest investment in global infrastructure of all time, easily outpacing the United States' Marshall Plan following World War II. ${ }^{1}$ As one of the signature projects of President Xi Jinping, the

1 This is true at least in terms of the total amount of money at stake. For a more detailed discussion comparing the grant and loan structures of the Marshall Plan and the BRI, see "Will China's Belt and Road Initiative outdo the Marshall Plan?," The Economist, March 8, 2018. 
BRI officially aims to "promote the economic prosperity of the countries along the Belt and Road and regional economic cooperation, strengthen exchanges and mutual learning between different civilizations, and promote world peace and development."2 For many both inside and outside of China, the BRI is a welcome plank of China's new platform of global engagement. Indeed, China's increased international engagement is seen by many as both a fortuitous and logical response to the gap left by the United States' increasingly vexed relationship with international institutions.

Despite the BRI's aspirations, it has been called into question from an increasing range of perspectives. Competing regional interests, such as those of India, Indonesia, Malaysia, the Philippines, Vietnam, Australia, and Japan have raised both security and economic concerns. ${ }^{3}$ India, Japan, and Australia have joined the United States in what has been dubbed the "Quadrilateral Security Dialogue" to ensure a "free and open Indo-Pacific."4 The European Union has grown increasingly critical of the BRI on a range of issues from its departure from a liberal trade model to lack of protections for labor and for the environment. ${ }^{5}$ The human rights community has also raised serious allegations of abuses of workers and local citizens along the nodes of the Belt and Road. ${ }^{6}$ Although these are all important paths to pursue in gauging both the substance and impact of the BRI, in this article I am going to focus primarily on security questions raised from the American perspective. By placing the BRI in historical and global perspective, I will critically evaluate the questions

2 The State Council of the People's Republic of China, "Action plan on the Belt and Road Initiative," updated: March 30, 2015, 7:31 PM, http://english.gov.cn/archive/publications/ 2015/03/30/content_281475080249035.htm.

3 Timothy Saviola and Nathan Swire, "Water Wars: Conflict in the Maldives Between Major Powers," Lawfare, March 19, 2018, 8:00 AM, available at https://www.lawfareblog.com/water -wars-conflict-maldives-between-major-powers. "In South Asia, Chinese Infrastructure brings Debt and Antagonism," The Economist, March 8, 2018.

4 "In South Asia, Chinese Infrastructure brings Debt and Antagonism," The Economist, March 8, 2018.

5 Erik Brattberg and Etienne Soula, "Europe's Emerging Approach to China's Belt and Road Initiative," Carnegie Endowment for International Peace, October 19, 2018, available at https://carnegieendowment.org/2018/10/19/europe-s-emerging-approach-to-china-s-belt -and-road-initiative-pub-77536.

6 See, e.g., Sophie Richardson and Hugh Williamson, "China: One Belt, One Road, Lots of Obligations," Human Rights Watch, May 12, 2017 7:03 PM EDT, available at https://www .hrw.org/news/2017/05/12/china-one-belt-one-road-lots-obligations; Ben Mauk, "Can China Turn the Middle of Nowhere into the Center of the World Economy?," The New York Times Magazine, Jan. 30, 2019. https://www.nytimes.com/interactive/2019/01/29/magazine/china -globalization-kazakhstan.html. 
raised by American observers in order to separate the concerns we should take seriously from those that are overblown. The Belt and Road initiative and accompanying military buildup have been heralded as a fundamental change in the global order. Whether that is the case, of course, remains to be seen. What is certain, however, is that the balance of regional economic and military power is undergoing a dramatic change.

This article will proceed in three sections, with a general focus on the relationship between China's Belt and Road Initiative and China's expanding military. I will start by exploring some of the fears and concerns raised primarily by US political and military observers. Among the concerns, all of which began percolating long before the current administration in Washington, are whether the Belt and Road initiative is part of a plan not only for economic development, but also economic and military dominance. A central fear, expressed by a multitude of observers, is that China's Belt and Road Initiative will supply the infrastructure to control key trade routes and shipping lanes, thus threatening the economy of both regional rivals and the world as a whole.

After exploring some of the concerns raised by American observers, I will examine China's own Belt and Road narrative. A central message from China is that the BRI is about both economic development and building a coalition of developing nations who share economic interests. The BRI is thus a vehicle not only for economic fortune, but also the basis for promoting international institutions and legal developments that will better serve the interests of developing nations before developed ones.

In the final section of the article, I will raise some critical questions about both the American and Chinese narratives concerning economic interest and the rule of law. With a clearer understanding of the competing narratives in hand, I will turn to the most pressing challenge facing the two superpowers. Maintaining peace and security in water and airspace increasingly crowded by aircraft carriers and fighter jets is a challenge that both China and the United States need to take seriously. Meeting that challenge is not only critical for maintaining peace, but also global economic stability.

\section{American Concerns}

As many observers have noted, China's development engagement in Asia, Africa, and Europe is expanding at the same time that its military spending in general, and its naval forces in particular, are rapidly growing. In constant dollars, China's military spending has increased nearly eightfold over the last two 
decades. ${ }^{7}$ In the United States, China's aggressive defense of its interests in the South and East China Seas against competing claims to territory and energy rights is the subject of regular news features and Congressional hearings. ${ }^{8}$ In April 2018, Admiral Philip S. Davidson, Commander of the U.S. Indo-Pacific Command, admitted in pre-confirmation testimony that China's development of military bases in the South China Sea has made it "now capable of controlling the South China Sea in all scenarios short of war with the United States." ${ }^{\prime 9}$ While a rapidly increasing military presence in the South China Sea has received the most attention, China watchers are swiftly finding a growing list of concerns, including China's first overseas military base in Djibouti and its recent acquisition of a 99-year lease to a 15,000 acre Hambantota Port in Sri Lanka. Extrapolating from the experience in the South and East China seas, many now fear that China will continue to use the growing power of its military to assert its interests wherever they arise. They thus speculate that the BRI will be a vehicle for military dominance as much as economic development.

One way in which U.S. political and military officials have connected the BRI to the rapidly expanding People's Liberation Army Navy is via China's "costly commitment to developing aircraft carriers."10 The development of aircraft carriers are of particular concern because, it is argued, "China does not require aircraft carriers ... to contend with regional competitors, including the United States, to defend its maritime security."11 That is, "given the proximity of China's air and naval bases to its neighbor's defense facilities in the surrounding seas, including those in Japan, Taiwan, and the South China Sea countries," China already has sufficient air and naval power without carriers to protect its regional interests. China's aircraft carrier development has thus led

$7 \quad$ Military Expenditure by Country, in Constant (2016) US \$ m., 1949-2017, SIPRI Military Expenditure Database, Stockholm International Peace Research Institute, available at https://www.sipri.org/sites/default/files/SIPRI-Milex-data-1949-2017.xlsx.

8 See, e.g., Megan Specia and Mikko Takkunen, "South China Sea Photos Suggest a Military Building Spree by Beijing," New York Times, Feb. 8, 2018, available at https://www.nytimes .com/2018/02/08/world/asia/south-china-seas-photos.html.

9 Admiral Philip S. Davidson, Prepared testimony before the U.S. Senate Armed Services Committee, April 2018, "Advance Policy Questions for Admiral Philip Davidson, USN Expected Nominee for Commander, U.S. Pacific Command," p. 18, available at https:// www.armed-services.senate.gov/imo/media/doc/Davidson_APQs_04-17-18.pdf.

10 Robert S. Ross, "Nationalism, Geopolitics, and Naval Expansionism From the Nineteenth Century to the Rise of China," Naval War College Review 71 (2018), p. 21. Id. 
U.S. officials to conclude that China seeks to project power "out across the vast Pacific Ocean" far beyond its regional sphere of influence. ${ }^{12}$

One recent example that seems to confirm the suspicion that China will use its growing military might to enforce its economic interests is the entrance of a fleet of Chinese warships into the Indian Ocean earlier this year during the political crisis in the Maldives. Some observers saw this as the reason why India did not to attempt to intervene militarily in the Maldives crisis, despite India's historical close relationship with the archipelago and a request from the former Maldives president to do so. ${ }^{13}$ Indeed, just two months before the crisis "the Maldives signed a free trade agreement with China as part of the '21st Century Maritime Silk Road' project under the Belt and Road Initiative."14

As China continues to develop a navy with global reach, it will, of course, require overseas naval bases at strategic locations. For many observers, there is no better map of those locations than the "Road" of the BRI. ${ }^{15}$ In fact, China's first overseas naval base in Djibouti is located at a highly strategic point on the BRI's Road. The Djibouti base is located at the entrance to the Red Sea, through which much of the world's trade and natural resources flows. With China's recent extensive investment in Africa and increased military presence, it is poised to protect its economic interests and, some speculate, project power and control over the world economy.

For many, the naval base in Djibouti is just the first of many, ${ }^{16}$ and the BRI offers a roadmap not only of commercial, but also "naval expansion.,"17 The primary tool of turning what is officially described as development support for commercial ports into potential naval expansion is winning land concessions through what has been described as "debt-trap diplomacy."18 Observers

12 Quoted in Captain James Fanell's testimony before the U.S. House of Representatives Permanent Select Committee on Intelligence, May 17, 2018, "China's Global Naval Strategy and Expanding Force Structure: Pathway to Hegemony," p. 63.

13 Timothy Saviola and Nathan Swire, "Water Wars: Conflict in the Maldives Between Major Powers," Lawfare, March 19, 2018, 8:00 AM, available at https://www.lawfareblog.com/ water-wars-conflict-maldives-between-major-powers.

14 Id.

15 See, e.g., Keith Johnson and Dan De Luce, "One Belt, One Road, One Happy Chinese Navy," Foreign Policy, April 17, 2018, 8:00 AM, available at https://foreignpolicy.com/2018/04/17/ one-belt-one-road-one-happy-chinese-navy/.

16 Jeffrey Becker and Erica Downs, "China's Djibouti Military Base the First of Many," East Asia Forum, June 27, 2018, available at http://www.eastasiaforum.org/2018/06/27/ chinas-djibouti-military-base-the-first-of-many/.

17 Captain James Fanell's testimony before the U.S. House of Representatives Permanent Select Committee on Intelligence, p. 9 .

18 Ben Mauk, "Can China Turn the Middle of Nowhere into the Center of the World Economy?". 
are increasingly pointing to debt-financing itself as a tool that China is using to gain control and influence around the world, while also supporting its own military expansion. That is, China is alleged to be "seducing cash-poor countries with infrastructure projects that are unlikely to generate enough revenue to cover the interest on the loans that funded them."19 A study last year by the Centre for Global Development in Washington, DC, identified eight BRI countries that are at "particular risk of debt distress." 20 These include both Djibouti and Pakistan, the latter of which is the site of a port in Gwadar, which many speculate will be the site of China's second overseas naval base. ${ }^{21}$ The principle case in point, however, is China's recent acquisition of a 99-year lease to a 15,000 acre Hambantota Port in Sri Lanka. China extended a loan to Sri Lanka for the construction of the port. However, when Sri Lanka fell behind on its debt servicing, China negotiated the long term land concession. Although the Hambantota Port cannot be used for military purposes without Sri Lanka's express permission, observers are quick to point out that all of the ports that make up the "Road" of the BRI are capable of dual civilian and military use. According to analysts, the Hambantota Port is just one significant example of high-risk debt financing to be followed by land concessions. They believe many more cases of land concessions to avoid loan defaults are likely to follow. These examples seem to confirm the suspicion that Belt and Road is as much about China's expansion as it is about foreign development.

If we take a step back from the worst fears expressed by American political and military observers, we may see a more benign picture. After all, the fact that economic and commercial expansion is accompanied by military expansion should be neither surprising nor controversial. Commercial and military relationships have historically gone hand-in-hand. Moreover, since World War II, there has been no country that has pursued a combined vision of economic

\footnotetext{
19 Id.

20 John Hurley, Scott Morris, and Gailyn Portelance, "Examining the Debt Implications of the Belt and Road Initiative from a Policy Perspective," Center for Global Development, CGD Policy Paper 121, March 2018, p. 1, 16-19. See also, "In South Asia, Chinese Infrastructure brings Debt and Antagonism," The Economist, March 8, 2018.

21 See, e.g., Minnie Chan, "First Djibouti ... now Pakistan Port Earmarked for a Chinese Overseas Naval Base, Sources Say," South China Morning Post, January 5, 2018, 11:34 PM, available at https://www.scmp.com/news/china/diplomacy-defence/article/2127040/first -djibouti-now-pakistan-port-earmarked-chinese.
} 
and commercial growth supported by military expansion more than the United States. The U.S. reportedly has established nearly eight hundred military bases around the world, on every continent except Antarctica. ${ }^{22}$ Moreover, the U.S. makes no secret of the tightly interwoven relationship between its military and economic interests. For example, just a year ago, when the uss Carl Vinson, a U.S. nuclear-powered supercarrier, visited Vietnam-marking the first visit "made by a U.S. warship of its size since the end of the Vietnam War in 1975"23_Vice Admiral Phillip Sawyer, commander of the U.S. Seventh Fleet, described the American visit as about the "relationship with Vietnam, both [as] a military relationship and [as] a comprehensive partnership relationship."24 The "comprehensive partnership relationship" includes trade and commercial interests, regional stability and security, and international leverage in an area where the United States is no longer the sole super-power.

It should also be noted that the United States, and many other nations, have used debt-financing as a tool to secure their own economic and strategic interests around the world. It is, for instance, the express policy of the International Monetary Fund and the World Bank to promote liberal market economies with minimal trade barriers as a condition of their loans. ${ }^{25}$ Even the United States' generous grants to Europe and Japan after World War II were conditioned on adopting "market-friendly policies" such as the removal of trade barriers. ${ }^{26}$ The United States continues to pursue similar policies through strategic lending up through the present. While America's growing deficit and the extent to which it is foreign owned are widely known in the United States, what is less well-known is that the United States also holds trillions of dollars in foreign debt. ${ }^{27}$ Thus China is far from alone in pursuing economic and military interests through foreign developments and debt financing.

22 David Vine, "Where in the World Is the U.S. Military?," Politico, July/August 2015, available at https://www.politico.com/magazine/story/2015/o6/us-military-bases-around -the-world-119321.

23 Timothy Saviola and Nathan Swire, "Water Wars: Conflict in the Maldives Between Major Powers," Lawfare, March 19, 2018, 8:00 AM, available at https://www.lawfareblog.com/ water-wars-conflict-maldives-between-major-powers.

24 Id.

25 See, e.g., "Global Trade Liberalization and the Developing Countries," International Monetary Fund, November 2001, available at https://www.imf.org/external/np/exr/ $\mathrm{ib} / 2001 / 110801 . h t m$.

26 "Will China's Belt and Road Initiative outdo the Marshall Plan?," The Economist, March 8, 2018.

27 Comparative IMF data on U.S. government borrowing and lending is available here: https://fred.stlouisfed.org/series/GGNLBAUSA188N. 
If we take a further step back from the increasingly popular American narrative of underhanded dealings driven by a thirst for military domination, we will quickly see that there is another side to the story. There are several straight-forward considerations that might explain China's trade and military expansion. For example, just five years ago in 2014 China became the world's largest oil importer and increasingly reliant on international trade. ${ }^{28}$ China also faces growing instability in the global order with an anti-globalist U.S. president, a fractured European Union, the rise of populist and nationalist movements across the West, and unabated armed conflict across much of the Middle East and Africa. Quite simply, China can no longer count on western powers to maintain international economic, trade, and energy stability. China can thus be readily seen as filling a global stability vacuum left by western powers. ${ }^{29}$

For its part, China has made no secret of its perceived vulnerabilities and how it intends to respond to them. In "China's Military Strategy, a defense white paper prepared by China's State Council in 2015, the Chinese government unequivocally stated that:

With the growth of China's national interests, its national security is more vulnerable to international and regional turmoil, terrorism, piracy, serious natural disasters and epidemics, and the security of overseas interests concerning energy and resources, strategic sea lines of communication (SLOCs), as well as institutions, personnel and assets abroad, has become an imminent issue. ${ }^{30}$

Given these threats, the white paper goes on to outline a number of security priorities, amongst which are "to safeguard China's security and interests in new domains" and "to safeguard the security of China's overseas interests." 31 The white paper makes the link between its naval growth and these "new domains" and "overseas interests" crystal clear:

28 Timothy R. Heath, "China Prepares for an International Order After U.S. Leadership," Lawfare, August 1, 2018, 8:31 AM, available at https://www.lawfareblog.com/china -prepares-international-order-after-us-leadership.

29 Id.

$30 \quad$ "China's Military Strategy," The State Council of the People's Republic of China, White Paper, May 27, 2015, available at http://english.gov.cn/archive/white_paper/2015/05/27/ content_281475115610833.htm.

Id. 
The seas and oceans bear on the enduring peace, lasting stability and sustainable development of China.... [G]reat importance has to be attached to managing the seas and oceans and protecting maritime rights and interests. It is necessary for China to develop a modern maritime military force structure commensurate with its national security and development interests, safeguard its national sovereignty and maritime rights and interests, protect the security of strategic SLOCs and overseas interests, ... so as to provide strategic support for building itself into a maritime power. ${ }^{32}$

China's official military strategy makes quite explicit that it is pursuing a strong naval force as the logical corollary to its "development interests." Thus rather than the BRI serving as a mask for a hidden military agenda, China has been completely forthright in developing an explicit military agenda to support the Belt and Road.

If we look more closely at China's military spending, we can also see a different picture emerging. Although many call attention to China's increased military spending in total dollars, few note that, as a percentage of both GDP and total government spending, China's military spending has actually decreased over the last two decades and remains just a fraction of U.S. military spending. ${ }^{33}$ Thus while China's military is indeed rapidly expanding, that expansion is actually outpaced by China's growing economy and by its superpower rival.

China's growing engagement with international institutions may also provide some explanation for its growing military. For more than a decade, China has contributed more troops to UN peacekeeping missions than all other permanent members of the Security Council combined. ${ }^{34}$ China's investment in Africa has also gone hand-in-hand with increased security operations,

32 Id.

33 Over the same period, U.S. military spending is up slightly as a percentage of GDP and essentially flat as a percentage of total government spending. See The World Bank, Military Expenditure (\% of GDP), available at https://data.worldbank.org/indicator/MS.MIL.XPND.GD.ZS; and Military Expenditure by Country as Percentage of Government Spending, 1988-2017, SIPRI Military Expenditure Database, Stockholm International Peace Research Institute, available at https://www.sipri.org/sites/default/ files/SIPRI-Milex-data-1949-2017.xlsx.

34 See data available through United Nations Peacekeeping, Troop and Police Contributors, Open Data Portal, available at https://peacekeeping.un.org/en/data-troop-and-police -contributions; and Bates Gill and Chin-Hao Huang, China's Expanding Role in Peacekeeping, Stockholm International Peace Research Institute, November 2009, p. 1, available at https://www.sipri.org/sites/default/files/files/PP/SIPRIPP25.pdf. 
including counter-terrorism and anti-piracy operations around the horn of Africa. Specifically with respect to the naval base in Djibouti, Chinese defense ministry spokesman Ren Guoqiang said that the naval base would enable China to "better fulfil China's international responsibilities including antipiracy work and to maintain the peace and stability of Africa and the world." ${ }^{35}$ Whatever strategic interest China's economic and military expansion may serve, China is also contributing to global order and stability, often in ways that outstrip western contributions.

China's increased role in the global order is, in fact, aided by America's latest international recalcitrance. The United States' recent rejection of global institutions and partnerships, as evidenced by its threats to the International Criminal Court, withdrawals from the Human Rights Council, the Paris Agreement, and the Trans-Pacific Partnership, all bolster China's self-positioning as a defender of the rule of law, global institutions, and international stability. While the U.S. appears to be increasingly adopting unilateralist policies, China is only increasing its international engagement. As some commentators have pointed out, China's growing role on the international stage has allowed it to leverage its leadership position to gain both political and economic allies in the growing trade war with the U.S. ${ }^{36}$

In the current environment of increased security threats, European uncertainty, and American unilateralism, many in China perceive a "global governance deficit" and are making explicit calls for increased Chinese engagement. ${ }^{37}$ It is thus natural for China to pursue a "global network of partnerships." China quite understandably views such partnerships as critical to maintaining "global trade and investment," as well as international security.38 Moreover, China is pursuing this strategy with an alliance of developing countries with a priority on meeting their needs and values over those of developed nations. ${ }^{39}$ As Xi Jinping himself declared, China "must make the international order more reasonable and just to protect the common interests of China and other developing countries." ${ }^{30}$ Indeed, the Belt and Road Initiative is at

35 Jeffrey Becker and Erica Downs, "China's Djibouti Military Base the First of Many," East Asia Forum, June 27, 2018, available at http://www.eastasiaforum.org/2018/o6/27/ chinas-djibouti-military-base-the-first-of-many/.

36 Heath, "China Prepares for an International Order After U.S. Leadership."

37 See, e.g., Liu Chang, "Global Governance Deficit Calls for Broader Chinese Engagement," XinhuaNet, April 6, 2017, 11:33 AM, available at http://www.xinhuanet.com/english/2017 -04/06/c_136186941.htm.

38 Heath, "China Prepares for an International Order After U.S. Leadership."

39 Id.

40 Quoted in Heath, “China Prepares for an International Order After U.S. Leadership.” 
the center of its foreign policy strategy to bring developing nations together through their shared interests, while doing so without attempting to impose a political or economic ideology on its new partners.

Whether the partnerships China is pursuing will prove adequate to support China's interests, or even if there is enough in common among the various nations to bind them together, remains to be seen. Nevertheless, the Belt and Road initiative is certainly an attempt to bind a multiplicity of diverse nations together through shared economic interest. China is seeking to support the BRI's focus on trade and development with political and cultural outreach and dialogue. Reportedly, the Chinese Community Party (CCP) "intends to invite 15,000 members of foreign political parties to China for exchanges. ${ }^{41}$ These exchanges have been long in the making, as the CCP has cultivated contacts with hundreds of political parties in more than 150 countries. ${ }^{42}$ China's hopes is that by building consensus on "global economic governance" among diverse nations and political systems it will be able to unite those states around their common interests.

China is thus not just pursuing economic and strategic military interests. It is clearly also pursuing political interests on the world stage. China is avidly using the tools of global governance and international law to pursue its interests, specifically by reaffirming the importance and centrality of the United Nations, international institutions and cooperation generally, and the core principles of international law. ${ }^{43}$ As such, China has increased its active involvement with the United Nations, the G2o, and the International Monetary Fund (IMF). For instance, since the 2008 financial crisis China has been active in persuading the IMF to include its own currency, the Renminbi, in the IMF's Special Drawing Rights. By doing so, China has arguably made itself a more central player in the international monetary system, while also decreasing, even if only slightly, the international monetary system's focus on the U.S. dollar. ${ }^{44}$ In addition to emphasizing the importance of cooperation in international institutions, China has also helped establish rival institutions to further its goals, such as the Asian Infrastructure Investment Bank (АIIB) as an alternative to the Asian Development Bank. ${ }^{45}$ The AIIB is an excellent

\footnotetext{
41 Id.

42 Id.

43 Id.

44 For more detailed discussion, see Jue Wang, "China-IMF Collaboration: Toward the Leadership in Global Monetary Governance," Chinese Political Science Review 3 (2018), p. 63.

45 Tamar Gutner, "AIIB: Is the Chinese-led Development Bank a Role Model?," Council on Foreign Relations, June 25, 2018, available at https://www.cfr.org/blog/aiib-chinese -led-development-bank-role-model.
} 
example of China's alternative approach to lending in support of development in accordance with its own values of non-interference in the local politics of the receiving country. ${ }^{46}$ China is bringing the same approach to its support for development through the BRI.

In response to the fears raised in the West about China's increasing economic and military presence around the world, China can simply respond that it is filling a power vacuum left by western disfunction. Moreover, it is doing so in the name of developing nations around the world, through international institutions, and with an emphasis on the rule of law, especially non-interference in the domestic affairs of sovereign states as enshrined in international law.

\section{$3 \quad$ Critical Questions}

Given the divergent nature of the American and Chinese narratives concerning the вRI and China's military expansion, it is natural to wonder which one is correct. It is worth recalling that the two narratives are not entirely mutually exclusive. As we have seen, several of the conspiratorial accusations launched against the Chinese, such as their military expansion in support of their economic interests abroad, are explicit foci of China's published military strategy. Nevertheless, while there are accurate and insightful aspects of each narrative, there are certainly also misleading and exaggerated elements as well. We have already seen some of the short-comings of the American narrative. In conclusion, I want to raise a few critical questions for the Chinese narrative, before turning to critical security challenge arising from the United States' and China's increased military confrontations.

A central critical question for China's own narrative is its recent emphasis on fazhi, or the rule of law. While China has extolled the rule of law as essential to international development and security, some have charged China with taking a "cost-benefit approach to law" that "erodes international norms and institutions." 47 These observers emphasize that "a stable, cooperative, rulesbased international order requires a commitment to the restraining power of

46 Robert J. Hanlon, "Thinking about the Asian Infrastructure Investment Bank: Can a China-Led Development Bank Improve Sustainability in Asia?," Asia \& the Pacific Policy Studies 4 (2017), p. 541.

47 Maj. Ronald T.P. Alcala, Lt. Col. Eugene (John) Gregory and Lt. Col. Shane Reeves, "China and the Rule of Law: A Cautionary Tale for the International Community," Just Security, June 28, 2018, available at https://www.justsecurity.org/58544/china-rule-law -cautionary-tale-international-community/. 
the law," including against the Party and the state. ${ }^{48}$ For many observers, the central case in which China's cost-benefit approach has eroded international norms and institutions is China's denunciation of, and refusal to accept, the South China Sea Arbitration in 2016.

The International Tribunal of the Law of the Sea (IT LOS), the tribunal established pursuant to Annex VII of the 1982 UN Law of the Sea Convention of which China is a party, rejected many of China's territorial claims in the South China Sea. Despite the largely unfavorable ruling from ITLOS in its dispute with the Philippines, China has continued to militarily back expansive and legally suspect claims in the South China Sea. These actions have led some observers to conclude that in the South China Sea today, "international law and freedom of navigation norms are slowly giving way to the law of raw power and control. And China appears to be winning." ${ }^{\prime 9}$ At the very least, China appears to be putting its own interests ahead core principles of international law, particularly respect for the sovereignty and territorial integrity of other states. It is true, as some commentators critical of China's poor behavior in the South China Sea are forced to admit, that the United States and other powerful nations also frequently approach international law in a "pragmatic" fashion that serves their interests first and foremost. ${ }^{50}$ Thus China is not alone in rejecting the rule of law when it does not serve its core interests. Nevertheless, there is little doubt that strong state exceptionalism, whether by the U.S., Russia, China, or any other state, erodes international peace and stability. We should thus criticize such "pragmatic" approach to international law and institutions for their unlawfulness and destabilizing effects wherever they arise.

In fact, it is the strain that China is putting on the rule of law that leads to the more serious question of whether China's approach to South China Sea is raising an imminent danger of armed conflict erupting between superpowers. For as China increases its territorial claims and military presence in the South China Sea, the United States has responded to what it views as a threat to regional stability and its own position of power in the region. The U.S. has increased freedom of navigation operations (FONOPS) designed to assert both its own military might and defend the territorial claims of its close allies. As a result, there have been an increasing number of military encounters between Chinese and US warships and military planes. This tit-for-tat exercise heightens

48 Id.

49 Mark Nevitt, "The South China Sea's Muddled and Increasingly Militarized Future," Just Security, June 1, 2018, available at https://www.justsecurity.org/57279/south-china -seas-muddled-increasingly-militarized-future/. 
the possibility of a mishap between the two militaries that could spark broader conflict. ${ }^{51}$ Without some greater degree of cooperation and actual respect for the rule of law, tensions between the U.S. and Chinese militaries will continue to rise.

It is fair to say that avoiding military conflict between the United States and China is in everyone's interest. As China becomes a much greater player on the world stage, pursuing its own economic and strategic interests while increasing global order and stability should be a priority. While its rivals may not always make conflict avoidance easy, China's role as a world superpower and the dominant regional actor will also give it greater responsibility. The coming years will tell us whether China will be successful through the Belt and Road Initiative in promoting greater political, economic, and military stability regionally and around the world. The real test for China, however, will be whether it can promote its interests and those of other developing nations, while also reinforcing a truly international understanding of the rule of law.

$51 \quad$ Id. 